\title{
CHARACTERISTICS OF YOUNG LEARNERS' PSYCHOLOGICAL WELL-BEING AND SELF-ESTEEM IN PHYSICAL EDUCATION LESSONS
}

\author{
Rolandas Jančiauskas \\ Klaipèda University, Klaipèda, Lithuania
}

\begin{abstract}
Research background and hypothesis. The learners experience stress and anxiety at school because of bullying, and routine stressors are perceived as the dangerous ones. Therefore, they even do not want to go to school. Young learners' psychological well-being and self-esteem is good, and the children experience positive emotions in physical education lessons.

Research aim. The aim of the research was to analyze young learners' self-esteem and psychological well-being in physical education classes.

Research methods. Young learners' self-esteem and psychological well-being in physical education lessons were analyzed in Klaipeda city schools using an anonymous questionnaire survey method.

Research results. Summarizing the research results of learners' psychological well-being, it can be noted that psychological well-being of $41.0 \%$ of learners in physical education lessons was good or very good. Analysis of the results of young learners' self-esteem in physical education lessons showed that $41.0 \%$ of learners estimated themselves as the average ones.

Discussion and conclusions. Although young learners like attending physical education lessons, and they find the lessons easy, interesting, pleasant, good and useful, they feel unsafe in physical education lessons because they suffer from other children's bullying. There were cases when they did not want to go to physical education lessons at all.
\end{abstract}

Keywords: bullying, stress and anxiety, reluctance to go to school.

\section{INTRODUCTION}

ccording to L. Rupšienè and
J. Andriukoniene (2002), we usually tend
to think that all the children want to learn and gladly attend lessons in the primary school, but it is not true. Attribution of primary school learners' reluctance to learn is characterized by three features related to pupils' evaluation and fear, to the fatigue as well as the need for alternative activities. Primary school learners' unwillingness to learn at school is related to the evaluation at school and the desire to maintain positive self-evaluation. According to L. Rupšienè (1996), most children (95.0\%) want to go to the first class, but after four years of education their willingness to learn reduces significantly. Even
$15.0 \%$ of the fourth class learners say they do not feel well at school. However, it is important to create favorable psychological atmosphere that protects children from psychological stress and negative environment in order to develop a free and creative learner's personality, his/her mental strength and intelligence. When a child begins attending school, it is very important how other people treat him or her, whether he or she is recognized by adults and children. However, it is important for the child to evaluate himself/herself adequately because an inadequate self-evaluation distorts the personality, makes favorable conditions for the formation of negative features and complicates a normal mental 
development of the child. Evaluating oneself too well, a child may overlook the shortcomings, ignore failures and blame others for mistakes. A mistrustful child is sensitive to criticism and feels upset about failures. It is important that every child in the class felt safe and loved by others, and the promoting their independence and individuality. If a child is viewed negatively by other people, he/she develops anxiety and fear of failure. If a child constantly suffers from school teachers and classmates' negative evaluations, he/she can develop emotional and behavioral disorders and aggressive behavior. Young learners begin to organize themselves into groups and defend their group interests as their own ones. Thus, it awakens a strong motivation to belong and it increases children's aggressiveness, which often manifests as violence towards other children. According to V. Pursues and G. Tuzienè (2011), aggressive behavior with fellow learners not only impedes positive communication and educational process itself, but also lays the foundation to further spread of aggression in society. Violence at school and beyond its boundaries is a widespread and complex social phenomenon now, and the most common form of violence at school is bullying among pupils. According to the survey data of I. C. Overholser, E. H. Nasser (2000), learners experience stress and anxiety at school because of bullying, and routine stressors are perceived as the dangerous ones. Therefore, they even do not want to go to school. A. S. Hall and I. Torres (2002) point out that learners estimating themselves as funny and happy are inclined to unadaptive behavior, and learners with low self-esteem are characterized by a disadaptive avoidance style more often than the learners with moderate self-esteem (Natvig et al., 1999). However, little research analyzing young learners' self-esteem and psychological well-being in physical education lessons has been carried out in Lithuania.

The aim of the research was to analyze young learners' psychological well-being and self-esteem in physical education lessons.

The object of the research was young learners' psychological well-being and self-esteem in physical education lessons.

Hypothesis: Young learners' psychological well-being and self-esteem is adequate, and the children experience positive emotions in physical education lessons.

\section{RESEARCH METHODS}

Pedagogical and psychological literature was reviewed and psychological well-being and selfesteem in physical education lessons was analyzed. Young learners' self-esteem and psychological wellbeing in physical education lessons was analyzed in Klaipeda City schools using an anonymous questionnaire survey method. The consent for the research was obtained from the school management, teachers, children and their parents. The respondents had the right to withdraw from the research at any time. They were chosen at random. It was attempted to choose a homogenous sample of respondents according to the age of respondents. The number of questionnaires distributed to the respondents was 250 . The children were instructed how to fill them in. As many as 222 respondents answered the questions. Research results were processed using SPSS 10.0 software.

The research of young learners' psychological well-being in physical education lessons was carried out using the assessment scale based on D. Beresnevičienè (1995) psychological well-being profiles. Six questions were included, such as "Do you like attending physical education lessons?" Response scale was formulated as follows: I like it very much, I like it, I somehow like it, I do not like it, I do not like at all. The respondents had to select the answer to the statements by choosing one of the five possible answers (answers were scored from -2 to 2). An overall index of psychological well-being in physical education lessons was determined by calculating the average evaluation of all six components.

A semantic differential scale modified according to the respondents' age was used to carry out a research on learners' psychological self-esteem in physical education lessons. The scale was formed on the basis of A. Suslavičius (1988) semantic differential method. Eight statements were used to analyze learner's self-esteem in physical education lessons. The beginning of statements was "I am". The statement ended as "Very friendly", "Friendly", "Almost friendly", "Unfriendly", "Very unfriendly". The respondents had to finish each statement by choosing the right ending. Selfevaluation is a process when an attitude towards oneself is formed (Adamonienė, 2003). According to B. Bitinas (2004), the adequate self-evaluation is not pedagogically optimal; the learner has to evaluate oneself slightly better than he/she really 
is. However, this overestimation must not cross the reasonable boundaries, a correct self-assessment is only possible when people do not raise themselves above others, underestimate their merits or positive characteristics, or on the contrary do not humiliate themselves, or depreciate their achievements and merits.

\section{RESEARCH RESULTS}

The survey showed that most children liked attending physical education lessons very much (64.0\%). Physical education lessons were easy, useful and interesting $(\mathrm{p}<0.05-0.01)$. It was determined that although children liked attending physical education lessons, they felt unsafe there because they suffered from other classmates' bullying and aggression. However, parents and teachers were not always informed about learners' grievances; they used to talk about it with friends. There were cases when they did not want to go to physical education lessons at all ( $\mathrm{p}<0.05-0.01)$. Therefore, the children without expecting teachers or parents' help, tried to solve problems themselves by responding to bullying and aggression in the same way.

Many respondents found physical education lessons easy (45.5\%); the children enjoyed attending these lessons because they were interesting, nice, successful and useful $(\mathrm{p}<0.05-0.01)$. However, some children found physical education lessons not always easy, they felt insecure because other learners did not talk or communicate with them, and there were cases of bullying that caused their reluctance to attend these lessons $(\mathrm{p}<0.05-0.01)$. Physical education lessons were very interesting (52.3\%), children liked attending classes, and they found the lessons easy and funly, they performed well in the lessons and the lessons were useful ( $p<0.05-0.01$ ), but the children felt insecure in physical education lessons because of other classmates' bullying. It is very important for teachers to timely notice children's communication gaps in physical education lessons, to teach children tolerance and understanding, to develop their humanistic attitudes and to create a friendly environment where children interacted with each other in a friendly manner, felt happy and did not feel anxious about possible situations of bullying.

Some of respondents (45.0\%) felt happy in physical education lessons and they liked attending these lessons because they were easy, interesting and the learners performed well, the lessons were useful ( $\mathrm{p}<0.05-0.01)$, but the children felt unsafe because of other learners' bullying. Abused children told their friends, teachers, and parents about their classmates' behavior and expected compassion and understanding. With no help provided, the children tried to show their abusers that the harassment did not bother them, and they did not talk or communicate with their abusers. There were cases when learners did not want to go to physical education lessons because of bullying, but $47.7 \%$ of children performed well in physical education lessons, they liked attending the lessons, found them easy, funny, interesting, and useful $(p<0.05-0.01)$. However, they felt insecure in physical education lessons because of other classmates' bullying. There were cases when they did not want to go to physical education lessons because of it $(\mathrm{p}<0.01)$.

Even $53.6 \%$ of respondents found physical education lessons very useful and liked attending them, because the lessons were easy, interesting, pleasant and the children performed well $(\mathrm{p}<0.05-$ 0.01 ), but the children did not feel safe in physical education lessons because of classmates' bullying. Children's opinion that physical education lessons were beneficial had a statistically significant inverse correlation with the children's views that they felt safe in the lessons $(\mathrm{p}<0.01)$. We can judge about the children's good or very good psychological wellbeing in physical education lessons by considering an overall psychological well-being index, where the majority of the responses were divided between zero and two.

A survey of young learners' self-esteem showed that $56.8 \%$ of children considered themselves as unfriendly. The survey revealed that children who considered themselves as unfriendly were humiliating other pupils in the class $(p<0.01)$, they were pushing, kicking, slandering, calling names and teasing $(\mathrm{p}<0.05-0.01)$. However, the children who considered themselves as strong, cheerful and happy did not humiliate others, they interacted with other children sensitively and with dignity.

As many as $48.2 \%$ of children considered themselves to be moderately strong. Children's opinion that physical education lessons were easy had a statistically significant inverse correlation with the children's evaluation as strong ones $(\mathrm{p}<0.05)$. Physically weaker children felt unsafe and underestimated in physical education lessons. They were worried that other learners would laugh at them in case of failure. Children's opinion that 
physical education lessons were useful had a statistically significant inverse correlation with children's self-evaluation as strong ones $(p<0.05)$. Children's self-evaluation as strong ones had a statistically significant inverse correlation with their well-being in physical education lessons $(p<0.01)$. Children who considered themselves physically strong were in a good mood in physical education lessons. Children's opinion that the lessons were pleasant had a statistically significant inverse correlation with their self-evaluation as strong ones $(\mathrm{p}<0.01)$. The study shows that the children who considered themselves friendly, strong, beautiful, smart, funny, happy and talented $(\mathrm{p}<0.05-0.01)$ did not feel safe and were worried about their failure, mockery and bullying in physical education lessons. They could not experience positive emotion and were feeling depressed. Therefore, teachers who notice a child failing to do a physical exercise or task must be supportive and encouraging. Also, teachers must involve the whole class into doing this, in this way teaching children sensitivity and humanity. A delicate interaction between a teacher and a learner may be disturbed failing to notice by child's failure when accomplishing a physical exercise in physical education lessons. The same might happen with an interaction between learners and their classmates who failed. A child who had suffered a failure, felt lonely, outcast and insulted begins to distrust himself/herself, to feel hatred for the teacher and classmates, which later turns into aggression.

Children (50.5\%) considered themselves to be somewhat beautiful, and $33.8 \%$ of them considered themselves to be ugly. The survey found out that children who considered themselves to be beautiful felt unsafe in physical education lessons because of their classmates' bullying. Children's opinion that physical education lessons were easy had a statistically significant inverse correlation with the self-evaluation as beautiful $(\mathrm{p}<0.01)$. Children who evaluated themselves as beautiful made fun of their classmates in defense for their dignity $(\mathrm{p}<0.05)$ and threatened them $(\mathrm{p}<0.01)$.

Even $58.6 \%$ of children considered themselves as moderately intelligent. Children's self-evaluation as intelligent had a statistically significant inverse correlation with an overall psychological well-being index $(\mathrm{p}<0.01)$. The study showed that children who considered themselves as smart, as well as children who considered themselves beautiful felt unsafe in physical education lessons because of children's bullying. They also used to protect their dignity by mocking at other children in class. Children who considered themselves smart used to mock at other classmates by beating, kicking and threatening them $(\mathrm{p}<0.05-0.01)$.

As many as $53.2 \%$ of children considered themselves to be sad. Children's self-esteem as happy ones had a statistically significant inverse correlation with an overall psychological wellbeing index $(p<0.01)$. Children who self-evaluated themselves as cheerful did not feel safe and happy in physical education lessons. In their point of view, the lessons where bullying and violence existed were useless.

Some of children $(23.9 \%)$ considered themselves to be moderately happy and $55.4 \%$ of children treated themselves as unhappy ones. Our research results differ from R. Bakutyte (2002) survey results which show that many respondents felt very happy and happy (respectively $45.2 \%$ and $42.8 \%$ ). Children's self-evaluation as happy had a statistically significant inverse correlation with an overall psychological well-being index $(\mathrm{p}<0.01)$. Children who felt happy stated that physical education lessons were not easy and interesting $(p<0.01)$ because they did not receive after children's support and compassion in case of their failure. Children who considered themselves as happy were abused in physical education lessons $(\mathrm{p}<0.05)$, they felt unhappy and said that such lessons were useless.

Even $44.6 \%$ of children considered themselves as calm and $39.6 \%$ of children considered themselves as nervous. The survey shows that children who evaluated themselves as calm felt safe in physical education lessons $(p<0.05)$, but if their classmates abused them, the children protected their dignity by kicking offenders. Children's self-evaluation as talented had a statistically significant inverse correlation with an overall psychological wellbeing indicator $(p<0.01)$. The survey determined that children who were gifted did not find physical education lessons easy, interesting and pleasant $(\mathrm{p}<0.01)$. Children who considered themselves as gifted did not find physical education lessons beneficial because of other classmates' bullying. The average number of children's self-esteem had a statistically significant inverse correlation with an overall psychological well-being indicator $(\mathrm{p}<0.01)$. Summarizing children's self-esteem research results, we suggest that most respondents self-evaluated themselves as average. 


\section{DISCUSSION}

Summarizing the results of learners' psychological well-being, we can state that psychological well-being of $41.0 \%$ of children was good or very good in physical education lessons. Although the majority of children liked attending physical education lessons, but the remaining children did not feel happy in the lessons because of other children's bullying. Taking into consideration the results we can say that it is necessary to develop children's mutual understanding and humanistic values, so that all the children wanted to attend physical education lessons and felt happy there.

According to A. Palujanskiene (2005) survey data, direct aggression occurs irrespective of sex because of different accentuations of character. The decline of values exists across the globe. Victims of bullying experience injustice, tension, feeling of helplessness (Targamadzè, Valeckienè, 2007). More than half of the learners feel a large increase in anxiety at school (Martišauskiene, 2004). Only $68.0 \%$ of learners willingly attend school after four years of learning at the primary school because of children's bullying and harassment (Rupšienè, 1996). Our survey found out that although children liked attending physical education lessons, and they found these lessons easy, useful and interesting, felt happy and did well, they felt unsafe in physical education lessons because they suffered from other children's bullying and aggression. There were cases when they did not want to go to physical education lessons. Feeling unsafe, being absent-minded and defensive against other learner's insults in physical education lessons, they behave impulsively and thoughtlessly, which negatively affects the learning process and encourages behavioral problems at the primary school (Giannopulu et al., 2008).

Our survey results coincide with the findings of V. Targamadzè and D. Valeckienè (2007) which show that learners suffer from harassment, intimidation and indirect forms of bullying - peer ignorance and rejection. It can be stated that children lack security. It is important for a child to be seen and accepted as he/she actually is. Being unable to meet these needs, the child loses the opportunity to love and to be loved. Thus, children having communication problems often become aggressive and demanding and are rejected by their peers (Pileckaitè-Markovienè, 2005). Bullying among primary schoolchildren is a primary manifestation of behavior which leads to violent behavior when the learners get older (Targamadzé, Valeckienè, 2007). Therefore, if members of the community tolerate children's violence and observe its manifestation in children's behavior indifferently, children grow up more aggressive in such environment.

However, children's aggressiveness can be adjusted by helping to realize their conflicting emotions, creating conditions for children where they can understand themselves and control their behavior. Thus, teachers must not tolerate inappropriate learner's behavior in physical education lessons and respond to it immediately, as well as discuss and analyze such behavior with all the learners in the class. Victims of bullying experience injustice, tension, and feeling of helplessness, which negatively affects both physical and emotional health of children. Such children have low self-esteem (Targamadzé, Valeckienè, 2007).

Discussing children's self-esteem results, it was determined that $41.0 \%$ of children considered themselves as the average ones. Most children liked attending physical education lessons and they felt happy there if other learners in class did not abuse them and helped them in case of failure.

The survey shows that learners who considered themselves unfriendly, bullied other pupils. Our survey data confirm M. PileckaitèMarkoviene (2001) statement that a child's failure to communicate causes a sense of inferiority which only enhances suffering from an internal disharmony and reveals itself through aggressive behavior with others. Children who considered themselves strong, beautiful, smart, funny, happy, and talented in physical education lessons did not like attending lessons because of other learners' bullying. They did not receive other children's support and compassion in case of failure, felt unhappy and said that physical education lessons were useless.

Children who evaluated themselves as beautiful, intelligent and gifted felt unsafe in physical education lessons because of other children's bullying. They also used to abuse other children in defense against bullying. Analyzing children's self-evaluation as the happy ones, our survey did not coincide with R. Bakutyte research results (2002) indicating that many respondents felt happy or very happy. The survey showed that only the children who considered themselves as calm 
felt secure in physical education lessons. However, if other children used to bully them they defended their dignity and used to abuse their offenders as well. In summary, it can be stated that although children like and find physical education lessons interesting, on the other hand, they are not always willing to attend physical education lessons because of other children's aggression and misbehavior. Therefore, in order to eliminate bullying and other negative behavior among young learners in physical education lessons, it is necessary to create a safe and functional learning environment where sincere relations among teachers and learners would be cherished and behavior of children with their classmates and teachers would change towards humanistic values.

\section{CONCLUSIONS AND PERSPECTIVES}

Although young learners like attending physical education lessons, and they find the lessons easy, interesting, pleasant, good and useful, they feel unsafe in physical education lessons because they suffer from other children's bullying. There were cases when they did not want to go to physical education lessons at all.

Children who considered themselves as strong, beautiful, intelligent, funny, happy and gifted felt unpleasant in physical education lessons because of other children's bullying. They did not receive other children's support and compassion in case of failure, and found such physical education lessons useless.

Our hypothesis was not proved because young learners most often evaluated themselves as the average ones. Psychological well-being in physical education lessons was not always good because of frequent cases of bullying which caused unwillingness to attend physical education lessons.

In order to eliminate bullying and other negative behavior among young learners in physical education lessons, it is necessary to develop educational programs and to implement them in practice. Also, it is important to develop humanistic values for children belonging to this age group by combining cognitive and emotional elements of learning, by providing a possibility to experience humanistic values and to put them into practice using active and playful activities.

\section{REFERENCES}

Adamonienè, R. (2003). Savęs vertinimas - asmenybès socializacijos dispozicija. Pedagogika, 66, 31-35.

Bakutyte, R. (2002). Jaunesniojo mokyklinio amžiaus vaikų požiūris į humaniškumą ir jo formavimo reikšmè. Pedagogika. Mokslo darbai, 56, 14-20.

Beresnevičienè, D. (1995). Nuolatinis mokymasis Lietuvoje. Psichologiniai pagrindai. Vilnius: Pedagogikos institutas.

Bitinas, B. (2004). Hodegetika. Auklejimo teorija ir technologija. Vilnius: Kronta.

Giannopulu, I., Escolano, S., Cusin, F., Citeau, H., Dellatolas, G. (2008). Teachers' reporting of behavioural problems and cognitive-academic performances in children aged 5-7 years. British Journal of Educational Psychology, 78, 127-147.

Hall, A. S., Torres, I. (2002). Partnerships in preventing adolescent stress: Increasing self-esteem, coping, and support through effective counseling. Journal of Mental Health Counselling, 24 (2), 97.

Martišauskienė, E. (2004). Mokyklinio nerimo ir dvasinès sklaidos paralelès paauglysteje. Pedagogika. Mokslo darbai. 73, 118-123.

Natvig, G. K., Albrektsen, G., Anderssen, N., Qvarnstrom, U. (1999). School-related stress and psychosomatic symptoms among school adolescents. Journal of School Health, 69 (9), 362-368.
Overholser, I. C. Nasser, E. H. (2000). Cognitivebehavioral treatment of generalized anxiety disorder. Journal of Contemporary Psychotherapy, 30 (2), 149161.

Palujanskienè, A. (2005). Paauglių agresija kaip charakterio akcentuacijų pasireiškimo forma. Pedagogika, 80, 132-140.

Pileckaitè-Markovienè, M. (2005). Santykių su bendraamžiais ir vidinès darnos sąsajos jaunesniame mokykliniame amžiuje. Ugdymo psichologija, 14, 7-12.

Pruskus, V., Tuzienè, G. (2011). Agresyvaus elgesio prieš bendramokslius priežastys, dažnumas ir formos: mokinių, mokytojų ir tėvų vertinimas. Filosofija, Edukologija, 19 (2), 181-197.

Rupšienè, L., Andriukonienė, J. (2002). Pradinių klasių moksleivių nenoro mokytis atribucija. Pedagogika, 62, 57-62.

Rupšienè, L. (1996). Šiuolaikinès pradžios mokyklos moksleiviu nuostatos mokytis. Moksliness praktinès konferencijos „Pradinis ugdymas: retrospektyva ir perspektyva" medžiaga. (pp. 196-200). Šiauliai.

Suslavičius, A. (1988). Semantinio diferencialo metodika. Vilnius: VU leidykla.

Targamadzè, V., Valeckienė, D. (2007). Patyčių bendrojo lavinimo mokykloje samprata: priežasčių, formų ir pasekmių diskursas. Acta Paedagogica Vilnensia, 19, 159-171. 


\title{
JAUNESNIOJO MOKYKLINIO AMŽIAUS VAIKŲ PSICHOLOGINĖS SAVIJAUTOS IR SAVIVERTĖS KŪNO KULTŪROS PAMOKOSE YPATUMAI
}

\author{
Rolandas Jančiauskas \\ Klaipédos universitetas, Klaipéda, Lietuva
}

\begin{abstract}
SANTRAUKA
Tyrimo pagrindimas ir hipotezè. Dèl vaiku patyčiu mokiniai mokykloje jaučia stresą ir nerimą, o iprastinius stresorius išgyvena kaip pavojingus, dèl to net nenori eiti i mokyklą. Jaunesniojo mokyklinio amžiaus vaiku psichologinè savijauta ir savivertè gera, o kūno kultūros pamokose jie patiria teigiamas emocijas.

Tikslas - ištirti jaunesniojo mokyklinio amžiaus vaikų psichologinę savijautą ir savivertę kūno kultūros pamokose.

Metodai. Klaipèdos miesto mokyklose anoniminès anketinès apklausos būdu buvo tiriama jaunesniojo mokyklinio amžiaus vaikų psichologinè savijauta ir savivertẻ kūno kultūros pamokose.

Rezultatai. Apibendrinant vaiku psichologinès savijautos tyrimo rezultatus galima teigti, kad $41,0 \%$ vaiku psichologinè savijauta kūno kultūros pamokose gera arba labai gera. Analizuojant jaunesniojo mokyklinio amžiaus vaikų savivertès kūno kultūros pamokose tyrimų rezultatus nustatyta, kad apie $41,0 \%$ vaikų save vertina vidutiniškai.

Aptarimas ir išvados. Nors jaunesniojo mokyklinio amžiaus vaikams patiko lankyti kūno kultūros pamokas, jų metu jiems buvo lengva, i̇domu, malonu ir gerai sekèsi, pamokos vaikams buvo naudingos, tačiau jie jautėsi nesaugiai. Dažnai mokiniai patirdavo kitų klasès vaikų patyčias ir yra buvę, kad dèl to net nenorèjo eiti i šias pamokas.
\end{abstract}

Raktažodžiai: patyčios, stresas ir nerimas, nenoras eiti į mokyklą.

Gauta 2012 m. balandžio 25 d.

Received on April 25, 2012 